3. Rigaud S, Fondanèche MC, Lambert N, Pasquier B, Mateo V, Soulas P, Galicier $L_{1}$, Rieux-Laucat F, Revy P, Fischer A, de Saint Basile G, Latour S. XIAP deficiency in humans causes an $\mathrm{X}$-linked lymphoproliferative syndrome. Nature 2006;444:110-114.

4. Lappalainen I, Giliani S, Franceschini R, Bonnefoy JY, Duckett C, Notarangelo LD, Vihinen M. Structural basis for SH2D1A mutations in X-linked lymphoproliferative disease. Biochem Biophys Res Commun 2000;269:124130.

5. Lanzkowsky P, Lipton JM, Fish JD. Lanzkowsky's Manual of Pediatric Hematology and Oncology, 6th ed. New York, Academic Press, 2016.
6. Patiroglu T, Akar HH, Unal E, Ozdemir MA, Karakukcu M. Hematopoietic stem cell transplant for primary immunodeficiency diseases: a single-center experience. Exp Clin Transplant 2017;15:337-343.

7. Milone MC, Tsai DE, Hodinka RL, Silverman LB, Malbran A, Wasik MA, Nichols KE. Treatment of primary Epstein-Barr virus infection in patients with X-linked lymphoproliferative disease using B-cell-directed therapy. Blood 2005;105:994-996.

8. Lee TL, Law HKW, Chan GCF, Ha SY, Ho MHK, Chan KW, Lau YL. Successful treatment of X-linked lymphoproliferative disease (XLP) with anti-CD20 monoclonal antibody (rituximab) followed by mismatched unrelated cord blood transplantation. Hong Kong J Paediatr 2006;11:210-214.

\title{
Intracranial Bleeding in a Female Hemophilia Patient: Molecular Analysis of the Factor 8 Gene and Determination of a Novel Mutation
}

\author{
Intrakraniyal Kanama ile Başvuran Hemofili A Olgusu: Yeni Bir Mutasyonun Moleküler Olarak \\ Tanımlanması
}

\author{
(D) Burçak Tatlı Güneş ${ }^{1}$, (D) Zühal Önder Siviş ${ }^{1}$, (D) Eda Ataseven ${ }^{1}$, (D Barış Malbora ${ }^{1}$, (D Meral Türker ${ }^{1}$, (D) Fatma Burcu Belen ${ }^{2}$, \\ (D) Berna Atabay ${ }^{1}$, (D) Tahir Atik ${ }^{3}$, (D) Esra Işık ${ }^{3}$, (D) Ferda Özkınay ${ }^{3}$ \\ ${ }^{1}$ Izmir Tepecik Training and Research Hospital, Clinic of Pediatric Hematology, Izmir, Turkey \\ ${ }^{2}$ Başkent University Faculty of Medicine, Department of Pediatric Hematology, Ankara, Turkey \\ ${ }^{3}$ Ege University Faculty of Medicine, Department of Pediatric Genetics, Izmir, Turkey
}

To the Editor,

An 11-month-old female patient was admitted to the emergency department with right occipital fracture and epidural hematoma. The father had severe hemophilia A and the parents were cousins. Laboratory tests revealed normal complete blood count and prolonged activated partial thromboplastin time. Mixing test results were normalized after mixing with normal plasma. After plasma samples were collected for further diagnostic tests, fresh frozen plasma and dexamethasone were administered. The factor VIII level was $0.1 \%, 35 \%$, and $0.5 \%$ for the patient, mother, and father, respectively. The patient's von Willebrand factor (VWF) level was $128 \mathrm{IU} / \mathrm{mL}$, VWF:Ricof was $110 \mathrm{IU} / \mathrm{mL}$, collagen ADP was 110 (reference: 71-118) s, and collagen epinephrine was 98 (reference: 85-165) s. Intron 22 inversion was investigated with the IS-PCR method and was found to be normal. Whole-genome analysis including all exonic regions of the F8 gene (NM_000132.3) was conducted and the homozygous c.608T>C (L203P) mutation was found.
This mutation was not previously reported. As this variant was not reported in any exome databases (ExAC, EVS) and as it was shown to be the cause of the disease in at least three in silico protein modeling programs, the mutation was considered as a novel mutation causing hemophilia A ("probably damaging" with 0.987 PolyPhen2 score, "disease causing" with 0.999 MutationTaster score, and "damaging" with 0 SIFT score). The mutation was also confirmed by Sanger sequencing (Figure 1). Plasma-derived FVIII at 2x500 IU/day was administered for 14 days followed by $300 \mathrm{IU} /$ week prophylaxis. Inhibitor screening at the $5^{\text {th }}$ and $10^{\text {th }}$ exposure days was negative.

Hemophilia $A$ is rarely seen in female patients due to skewed inactivation of the $X$ chromosome leading to inactivation of the wild-type $X$ chromosome, anomalies like Turner syndrome, or translocations, as well as homozygous/compound heterozygous mutations for hemophilia $A[1,2,3,4,5]$. The karyotype analysis of our patient revealed $46, X X$. The patient and the father were hemizygous and mother was heterozygous for the c.608T>C 


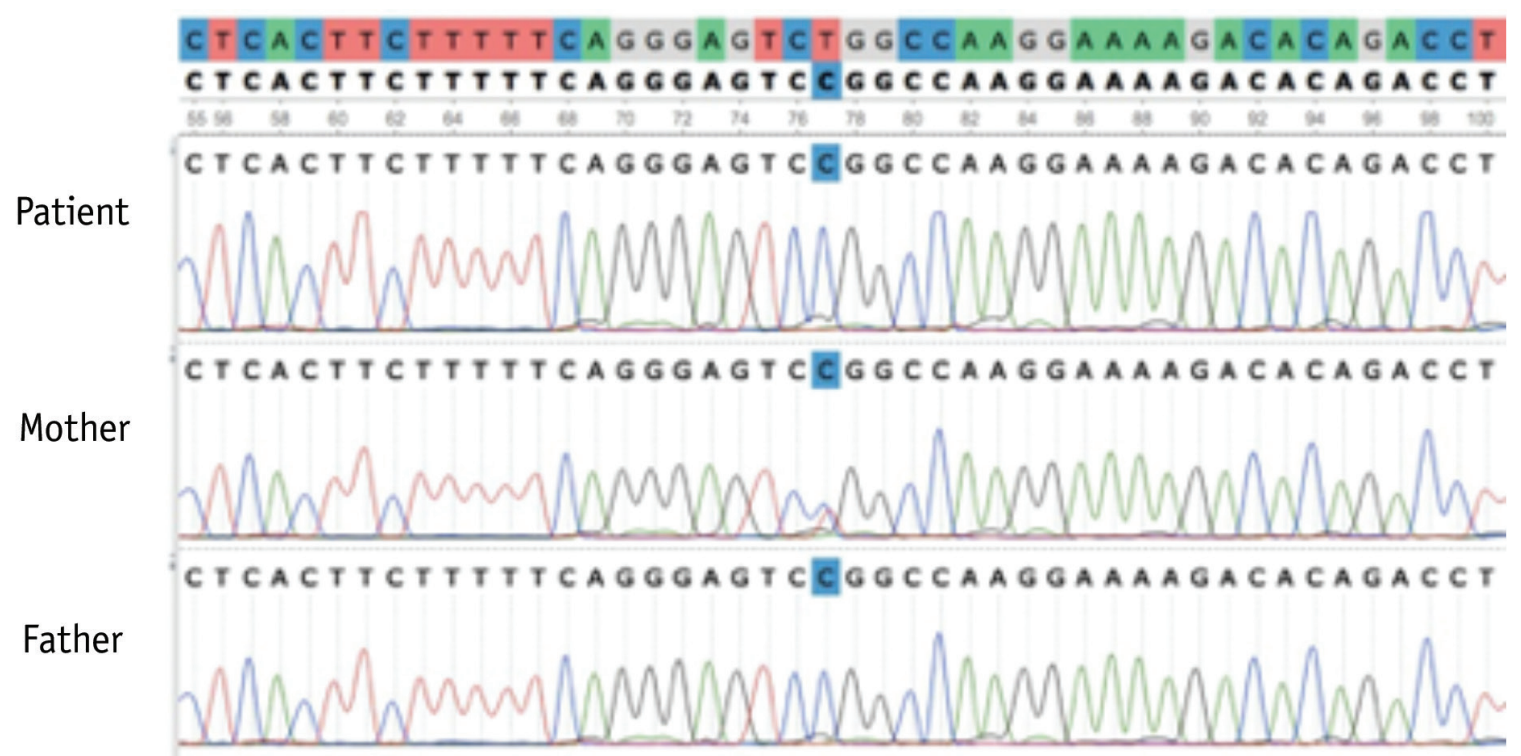

Figure 1. Sanger sequencing confirmation: (a) the mother (b), the father, and (c) the patient show heterozygous, hemizygous, and homozygous c.608T>C (L203P) mutation in the F8 gene.

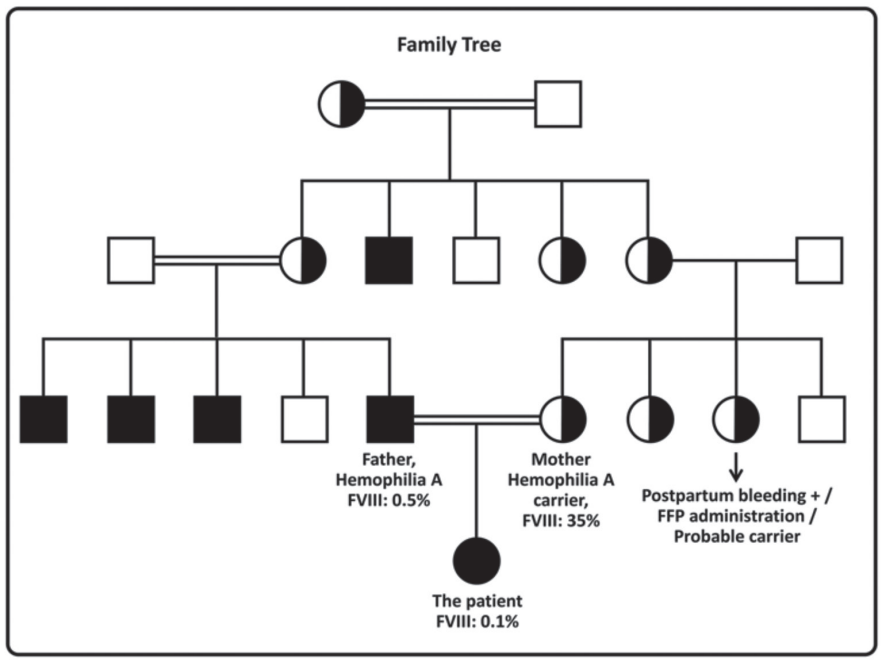

Figure 2. Family tree. The patient was homozygous, the father hemizygous, and mother heterozygous for the c.608T>C (L203P) mutation.

(L203P) mutation (Figure 2). The clinical situation of our patient as she was admitted with epidural hematoma requiring surgical intervention and the fact that the family did not apply for prenatal diagnosis before birth point out the importance of prenatal diagnosis in regions where consanguineous marriage is common.
Keywords: Hemophilia, Intracranial bleeding, Female

Anahtar Sözcükler: Hemofili, İntrakraniyal kanama, Kız cinsiyet

Conflict of Interest: The authors of this paper have no conflicts of interest, including specific financial interests, relationships, and/or affiliations relevant to the subject matter or materials included.

\section{References}

1. Knobe KE, Sjörin MJ, Soller MJ,Liljebjörn H, Ljung RCA. Female hemophilia A: two unusual cases caused by skewed inactivation. Haemophilia 2008; $14: 846-848$.

2. Renault NK, Dyack S, Dobson MJ, Costa T, Lam WL, Greer WL. Heritable skewed $\mathrm{X}$-chromosome inactivation leads to haemophilia A expression in heterozygous females. Eur J Hum Genet 2007;15:628-637.

3. Chuansumrit A, Sasanakul W, Goodeve A, Treratvirapong T, Parinayok R, Pintadit P, Hathirat P. Inversion of intron 22 of the factor VIII gene in a girl with severe hemophilia A and Turner's syndrome. Thromb Haemost $1999 ; 82: 1379$

4. David D, Morais S, Ventura C, Campos M. Female haemophiliac homozygous for factor VIII intron 22 inversion mutation, with transcriptional inactivation of one of the FVIII alleles. Haemophilia 2003;9:125-130.

5. Pavlova A, Brondke $H$, Müsebeck J, Pollmann $H$, Srivastava A, Oldenburg J. Molecular mechanisms underlying hemophilia $A$ phenotype in seven females. J Thromb Haemost 2009;7:976-982.

๑Copyright 2018 by Turkish Society of Hematology

Turkish Journal of Hematology, Published by Galenos Publishing House

Address for Correspondence/Yazışma Adresi: Fatma Burcu BELEN, M.D., Başkent University Faculty of Medicine, Department of Pediatric Hematology, Ankara, Turkey

Phone : +90 5325814551

E-mail : draidabb@gmail.com ORCID-ID: orcid.org/0000-0002-9278-6703
Received/Geliş tarihi: October 26, 2017 Accepted/Kabul tarihi: January 26, 2018

DOI: $10.4274 /$ tjh.2017.0385 